\title{
The Existence of Batik Esuk-Sore Pekalongan Style
}

\author{
Muhammad Arif Jati Purnomo \\ Department of Batik, Faculty of Fine Art and Design, Indonesian Institute of the Art, Surakarta, Indonesia
}

Email : ariefj4ti@gmail.com

\begin{abstract}
The purpose of this research is to examine the existence of Esuk-Sore batik style in Pekalongan. This research uses qualitative research methodology, with descriptive research form, supported by phenomenology theory of hermeneutics, sociology, and aesthetics. Research location covers Pekalongan City, and ex Residency of Pekalongan. The data sources include informants consisting of culturalists, historians, collectors, designers, batik entrepreneurs as well as data in the form of batik cloth artifacts, hard copies / soft copies of documents, sosifact and mentifact. The results of this study indicate the existence or existence of batik style Esuk-Sore in Pekalongan still maintained artifact, especially on sinjang. In the Esuk-Sore style is no longer used in marriage ceremony or welcome the Chinese new year, but essentially the concept of Esuk-Sore (concept of mix-match to produce harmony) is widely used for fashion trends that develop today.
\end{abstract}

Keywords: batik, Esuk-Sore style, Pekalongan.

\section{Introduction}

Long history of batik archipelago journey deserves to be studied and explored along with existence of batik which increasingly shows adi-luhung works of cultural heritage of Indonesia. The recognition of the world through UNESCO on batik as one of the Masterpieces of the Oral and Intangible Heritage of Humanity on October 2, 2009 in France, is one proof of its superiority and uniqueness. (Helen Ishwara, 2011, p. 19)

The tide of batik's glory is very closely related to the existence of special cloth as a base material or medium to incise hot wax on the surface of the fabric. Adequacy of materials is one of the conditions for the existence of batik appeared in a certain era in the era of modern batik. The existence of batik is very closely related to the motive or pattern, and the existence of motives or patterns associated with the style or trend that developed at a time.

History of batik development can not be separated from various terms that had emerged and popular in a period or a particular time. For example for batik inland or batik voorstenlanden there is called batik Larangan, batik Saudagaran, batik Babaran Wonogiren, and batik Harjonegaran. While coastal batik has more for example batik Djawa Hokokai, batik Djawa Baroe, batik Netherlands, batik Esuk-Sore style, batik Terang Bulan, batik Buketan, batik Rifa'iyah and so on.
Batik Esuk-Sore style is one of the styles or trends in the pattern of arrangement of motif for sinjang (long cloth) by dividing the two lengths of cloth with diagonal / oblique or straight line, where in the manifestation of the motif and the color is made unequal between one side with the other side. Generally one side of the background is dark, and one side of the other is bright background. These two contrasting are contradictory analogous to the different natural atmosphere between esuk (morning) which is illustrated with a bright background and sore (afternoon) depicted against a dark background. But in function this cloth becomes very interesting when this cloth can be used in two times without having to replace with another cloth. The bright background can be raised on the occasion of the afternoon or evening, while the dark background can be raised on the morning or afternoon. In Ostmeier's book the older, afternoon and afternoon-market terms which he gave other interpretations (Veldhuisen, 1993, p. 141)

From the historical record, the development of batik Esuk-Sore style has been around since 1890 in Banyumas made by mistress Matheron known as batik Matheron or Matheros (Veldhuisen, Batik Belanda 1840-1940, 1993, p. 123). Visually batik Esuk-Sore style on Matheron batik uses Sogan color (brown color or classic color in inland batik) which combine 
chrysanthemum motif on left side (one side) and motif Sekar Jagad on right side (other side). Subsequent developments, in about the 1930's before Japan occupied Indonesia batik Esuk-Sore style ever appeared in Kedung Wuni Pekalongan. At the time the existence of batik Esuk-Sore was widely used by women of Chinese descent. At Japanese occupation era, style or trend reappeared on any length of batik cloth "Djawa Hokokai".

The awakening of batik Esuk-Sore style in the history of batik development in Indonesia has always been associated with the period of Japanese occupation in Indonesia in the 1943 to 1945 , especially in the coastal areas of the north of Java Island, like Pekalongan. At that time the batik became one of the Japanese propaganda tools that symbolize a Japanese cultural dominance over Indonesia is visualized through every batik Djawa Hokokai. Each long cloth batik Djawa Hokokai always stylish batik Esuk-Sore but every style of batik Esuk-Sore is not necessarily batik Djawa Hokokai.

The limitations of mori as the main raw material of this batik is the main issue of the appearance of batik Esuk-Sore style. Although this is true but not fully accountable for the validity of the data. There are several things that have not revealed and studied that become the main cause of batik Esuk-Sore trend. Along with the passage of time that quickly changed the existence of batik batik Esuk-Sore style had experienced ups and downs, penetrating space and time to follow the development and changing times that always move dynamically.

Resilience factor is needed to be able to survive in innovating, transforming and morphed following the changing times. Some things that will be summarized in some research questions as a formulation of the problem in this study. From the description of the background of the above problems can be summarized into 2 point problems that can be used as guideline discussion of the point of the problem that will be reviewed some of this formulas are as follows:

(1) What is batik Esuk-Sore style and what is the background of the appearance of batik Esuk-Sore and (2) How is the existence of batik Esuk-Sore style from since the appearance of the style until now?

\section{Theoretical Basis.}

To answer the problem of what is batik Esuk-Sore style and the background of the appearance of batik Esuk-Sore style, there are several supporting theories borrowed in this study such as the theory of phenomenology hermeneutics, aesthetics and social theory. The existence of batik Esuk-Sore style in the middle of society whose situation and conditions are always changing to follow the times can not be separated from the social and cultural factors of the followers at that time. Because of the complex of the problems that directly related to the cultural life of the community, so the hermeneutical phenomenology and sociological analysis is appropriate to examine this issue. Kuntowijoyo explained that in a cultural institution will be questioned who produces cultural products, who controls, and how the control is done. For the content of the culture will question what is produced or what symbols are cultivated. While the cultural effects question the expected consequences of the cultural process. (Kuntowijoyo, 1987, p. 5). In line with the explanation of the cultural issues above Raymond Williams in his book Culture describes the contents of culture as follows: (i) the social and economic institution of culture and their alternative definitions of "product", of (ii) their content, and (iii) their affects (Williams, 1983, p. 17).

According to Umar Khayam (Kayam, 1981, p. 38). the growth and development of a culture in society is strongly influenced by the life of society in the day. Society is a buffer of culture and art that live according to the condition of culture that prevail in society life. Therefore, art as a buffer of cultural life is always in the middle of the culture of society, because art itself is the embodiment of culture. In relation to the social influence of coastal communities of Java Island in making batik Esuk-Sore style, in essence is strongly influenced by the role of followers community (Duvignaut, 1972, p. 12). It looks at the design patterns or patterns and colors created in this batik tend to be brighter, lively and dynamic, in line with the cultural conditions of coastal communities. Related to this to analyze the object material in the form of artwork used aesthetic theory from De Witt H Parker (Unity, Thema, Variation, Balance, Evolution, and Hierarchy). The existence of this aesthetic theory will be discussed as an indicator material that concerns the aesthetic values of an eastern work of art that is full of symbolic values. In analyzing an art phenomenon that arose in society according to Howard S Becker and Vera L. Zolberg stated about 4 elements supporting one social construction of art in one era are: (1) artist and his work; (2) the buffer society; (3) sociocultural institutions; (4) mediators (Becker, 1982, pp. 34-39). This is when implied in batik Esuk-Sore style is the first, the existence of the batik makers and their works. Second, the coastal communities in general and third, members of organizations or structural institutions that existed at the time. Fourth, the fabric brokers and batik traders on the coast of Java. The four supporting elements are each analyzed according to their function and existence according to their respective positions.

Records of the results of the four sources of social construction support are then analyzed to obtain a 
conclusion about the existence of batik-style Esuk-Sore seen from a social point of view.

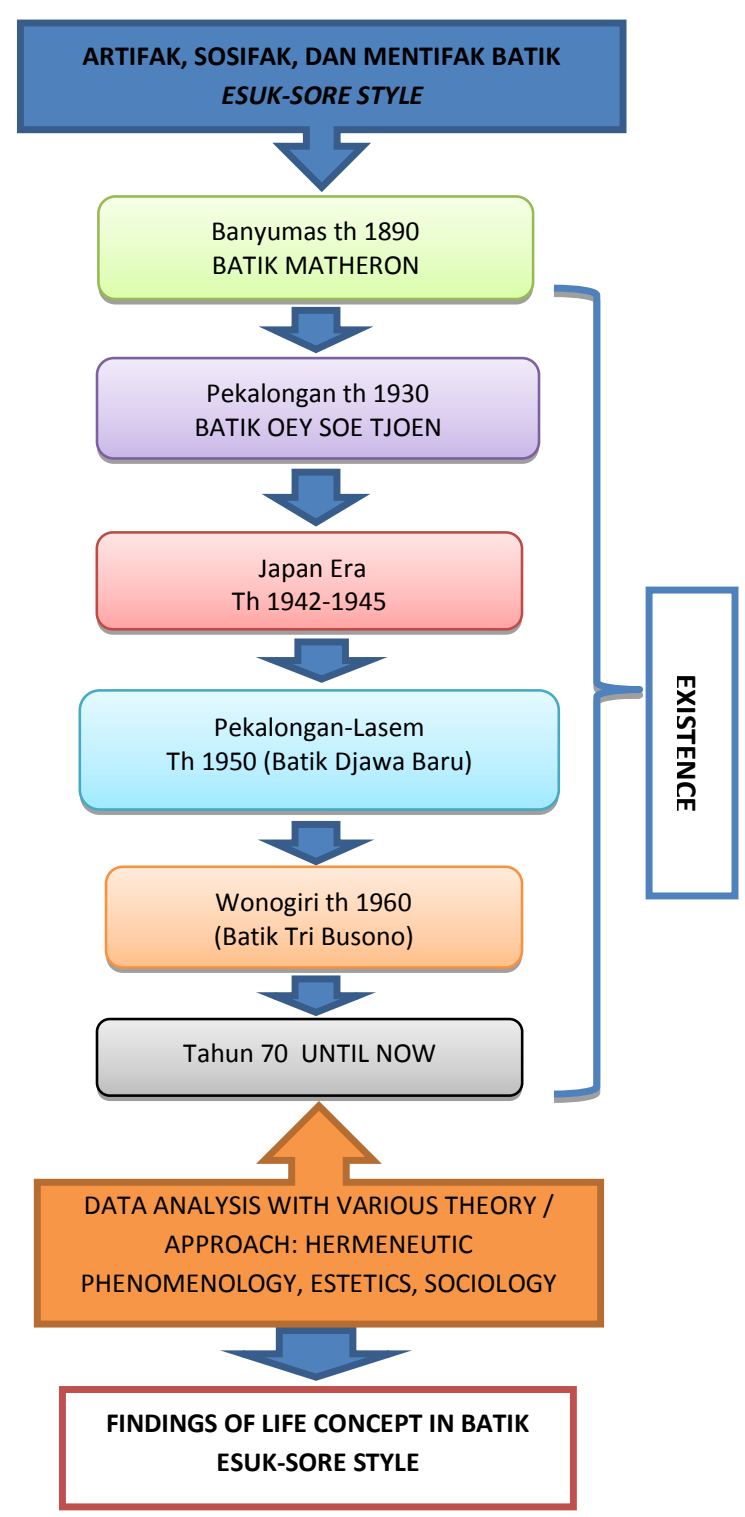

Figure 1. Framework

\section{Stakeholder and community views on batik Esuk-Sore style}

Batik sinjang with Esuk-Sore style as a cultural artifact that has the uniqueness of the visual patterns embodied on a piece of cloth rise to various interpretations of the community. From a variety of questions asked by researchers to the resource persons, cultural observers, artists, traders, collectors, batik lovers and the laity of the public brought a variety of unexpected answer statements by researchers. When the researchers brought the batik Esuk-Sore -style and they were asked to comment on the fabric appeared statements that are outside the frame of the researchers such as "the fabric is really weird, isn't it", "... very funny", "... Wow I want to have it"," ... this batik EsukSore is usual "," ... is it printing or batik ..? How much does it cost? ... ", ".. how to use it .. "," ... my mother has a cloth like this, .. emm what is the name of this batik..?, "... if i see batik cloth Esuk-Sore like this I became reminded of my late mother ", and many more comments about batik Esuk-Sore.

When they were asked about what was imagined, thought, remembered, and hope that came from a piece of cloth that the researchers showed them, their comments were also very diverse as "if I see this kind of fabric I can imagine me when I was a child. I often picked up with this cloth that has similar motifs like this "There are also comments:

"My parents used to have some cloth Esuk-Sore... I still remember that when I was invited to one of batik traders or rich people at that time. My mother brought some cloths like that and stayed at the merchant's house and my mother came home with enough money back then. When I asked my mother if the cloth was for sale, my mother shook her head, she said that it was only temporarily lent ... I have not really understood that the cloth was actually mocked by my mother as something of value "(interview with Dudung Ali Syahbana, 58 Year, living in Pekalongan, June 3, 2016)

Another case with comments from Istyanti Setyono, 64 years, second generation of Batik Art (batik Oey Soe Tjoen) Kedung Wuni Pekalongan when researcher presented batik cloth Esuk-Sore, with a glowing face he recalled:

"When I saw the batik cloth that I brought, I was reminded of my childhood, .... and if it is not the fabric that father brought it that makes this batik company. This batik is used to wear at certain times only, ... as when celebrating Chinese' special day here. We are so proud when we can wear this Esuk-Sore -style. In addition, this cloth Esuk-Sore is also a fabric that seems to be sacred, meaning for events like marriage of Chinese society here (Kedung Wuni) using the cloth Esuk-Sore, ... or if the Javanese batik use Sido Mukti . Perhaps because of the use of cloths that afternoon is only at very special times, then the design is made like that, means that one long cloth can be used from morning to night with different designs or different appearance, although in fact not replace the long cloth, just reversed the Esuk or the outside is put on the inside, so impressed wearing a different cloth. 
"(Interview with Istyanti's mother Setyono Mulyadi, 64 years, living in Kedung Wuni Pekalongan, 3 June 2016)

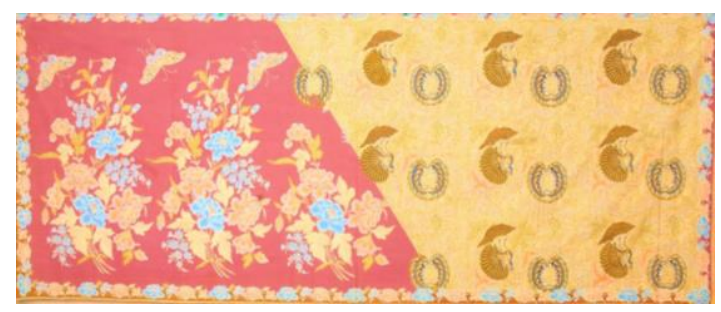

Figure 2. Batik Esuk-Sore style by Oey Soe Tjoen Batik Art Kedung Wuni (Doc: Muh Arif, 2016)

Unlike Istyanti's, middle-aged mother who is a successful property entrepreneur named Danarti, 43 years has a different impression with some of the above sources. When cloth Esuk-Sore of the researcher showed her, with teary eyes and a slightly bricked sentence she commented:

"I'm sorry sir, ... I have a little sensitive when I see the batik cloth that brought with Mr; frankly I was reminded of my close friend who I have considered like a brother. About two years ago, my friend was at home, he was a friend of my age school in high school, .... although he is of Chinese descent but my closeness with her like brother at that time. We are always together wherever and whenever. I don't know why both of us always be seemly even though he is Chinese and I am Javanese. Graduated from high school I studied at Economics faculty in UGM, and she did not continue her college, it seems that her parents were told to continue the business of her parents. Long time we both lost contact, ... but two years ago, I accidentally met her in a Mall, and made a pact to meet at home here ...... if it's not wrong, the day was Wednesday, my friend came home and I release her longing by telling each of our experiences after graduated from high school, ... and when she wanted to leave home she gave me batik cloth Esuk-Sore as Mr brought earlier. She said the cloth belonged to her parents that deliberately she gave to me, because she knew I am a batik lover. A few days after the incident, when I had the opportunity to go to Jakarta, I had time to stop by her house, ... but what really makes me sad, disappointed and do not believe ... her husband said that my friend just died two days ago, she said she had met her friend in Yogya, which is myself. According to her husband actually my friend was suffering from acute stage cancer that has been a long time, but not felt, and his departure to Yogya meet me as if willing to leave far away. At that time I was stunned by myself, do not know what to do, and please excuse me to go back to Yogya again. Then Mr, .. sorry, since then the cloth of giving my best friend that I kept in the most in the cupboard, so that memory remind me that quickly erased. (Interview with Danarti's mother, 43, batik collector, living in Yogya, June 17, 2016).

In addition there are also some informants who do not know and do not understand if there is batik EsukSore style with visual display of two patterns or different motifs between the right and left. Even with his innocence she asked what is this cloth? Is this cloth batik or printing ... and do not know what to comment on. Even when the researcher explained to her, she became interested in having and asking the price of the fabric that the researcher showed. As Rostami's mother, 50 , a wife of a member of the local parliament (DPRD) who is also active in many of his wife's official activities, he said:

"Woow, ... how weird and funny batik!, ... I do not know any batik has model like this, ... uh is this batik or printing? What is the name of this batik sir ...? May I buy this cloth....? How much does one cloth like this batik .... May I bargain 75 thousand, I want to make clothes with this motif. Usually I make a design that kept my subscriptions tailor I send home, I directed glike this, like that so and I am proud of my own design ... the fabric that Mr showed me had inspired me to make other clothes designs than others "(Interview with Rostami's mother, 50, female activist activity, living in Solo, June 12, 2016).

Different again like what was delivered by Mr. Afif Syakur, 50 years old, a batik collector, batik entrepreneur, and one of the organizers of batik lovers Sekar Jagad Yogyakarta. He said:

"Batik Esuk_Sore style as far as I know, from the story of my parents had indeed been booming in the Japanese era with batik Djawa Hokokainya. Indeed many observers of batik say, if the style of the early afternoon is the style of batik that arises because of the situation and conditions of the times. Its appearance and its existence are better known for the epoch of deficiency at that time, ... it lacks material or mori, lack of dye ... so when it was the most aggravated era of the economy at that time. Our parents used to tell us that during the Japanese occupation the clothes they used 
were made of gunny sacks, and mori or cotton became a luxury item. So if at that time appeared a work of batik extraordinary beautiful will arise a question ... how can like that ...? Back to the style of Batik-EsukSore, ... in my opinion actually the Esuk-Sore style that arises because the batik itself is a luxury, ... it used to be batik cloth can be made collateral in pawnshops. Ok, .. from there emerging economic considerations, especially from the users who are Chinese people, who declared "if it can be for two why make one" ... from this case the style of the Esuk-Sore that appears. "(Interview with Afif Syakur, 50 th, June 3, 2016

\section{Review of the meaning of batik Esuk- Sore style}

Batik Esuk-Sore style included in coastal batik (Djoemena, 1990, p.7) means that batik in the process of making is done outside the area of Karaton Surakarta Hadiningrat and Yogyakarta Adiningrat. The term coast here does not refer to geographical location on the sea front or coast but rather to the territorial division of two royal or kingdoms. There are some common characteristics in coastal or coastal batik, among others, does not contain much symbolic or philosophical meanings such as batik interior (Solo and Yogya). Nevertheless there are several coastal areas such as Cirebon, Indramayu, Pekalongan and Lasem which also have symbolic meaning embodied in the visual perwujudal of batik area, although only some motifs such as Mega Mendung motif, Peksi Naga Liman, Dredgers and so on.

Similarly with batik Esuk-Sore, the philosophy of symbolic meaning contained from the visual appearance of a long cloth that is divided into two parts with a line slash or straight is not much in the study and is known. In general, those who see the visual appearance of the fabric only interpreted a related limitation of a social condition of the times of deprivation, including in this case the shortage of the main raw material of batik maker, it is cloth. Limitations on the raw materials of these fabrics are creatively and innovatively embodied in a batik-style look, commonly called the Esuk-Sore style.

The development history of Batik Esuk-Sore style is usually associated with batik Djawa Hokokai, it is batik that developed during the Japanese occupation in Indonesia, in the period 1943 to 1945. Batik Djawa Hokokai first appeared in Pekalongan, which the term is associated with the organization propaganda formaed by the government of Japanese occupation in Indonesia, especially in Pekalongan. Djawa Hokokai means the Javanese Community Devotion Association, whose job as the government's propaganda media of the occupation at that time. The Japanese government orders many of these Hokokai fabrics to the "selected" batik craftsmen in Pekalongan in order to award or reward the top officials or members of the organization who are seen as contributing to the Japanese government.

Visually, the look of Djawa Hokokai batik, looks like a motif in general, only the note here is the style used using the style of Esuk-Sore. Every Djawa Hokokai batik cloth always performs Esuk-Sore style, but not all Esuk-Sore styles are batik Djawa Hokokai. It is possible that the existence of the Esuk-Sore trend is very closely related to such a style that had appeared in Pekalongan in 1930, before Japan occupied Indonesia. However, due to the booming authoritarian holder of power at that time was very strong with the instruction of making batik with the style of Esuk-Sore, the community of laying batik always associate between Esuk-Sore with the Japanese Age. Esuk-Sore as a visual adaptation strategy of Pekalongan society at that time. If you can say visual adaptation strategy is a local cultural wisdom (local genius), then the craftsmen community in Pekalongan able to beautiful and beautiful again bring up the trend of the previous year in line with the age situation that developed at that time.

From the literature, history records the early development of batik style Esuk-Sore originated from the area of Banyumas in the 1890s or the beginning of the 19th century AD In the mapping batik Nusantara, Banyumas Residency area including the "coastal" although not geographically on the edge of the sea or beach. Batik Banyumas or commonly called the "Banyumasan" more inspired by Dutch Batik. Mrs. Matheron is a figure of Banyumas batik entrepreneur who brought up the first Esuk-Sore style. (Veldhuisen, Batik Belanda 1840-1940, 1993).

The influence of batik Matheron is very strongly in Banyumas area, so batik community at that time to give the branded related characters that appear from Matheron batik works. The term of batik Matheron or Matheros is strongly dominates all the works of batik Banyumas that existed and appeared in the range of the 1890's.

A slash pattern that divides the two parts equally long between one side with another. Different motives functioned for different occasions (exp. Sekar jagad motives for daytime opportunities, and florals for an afternoon or evening opportunity)

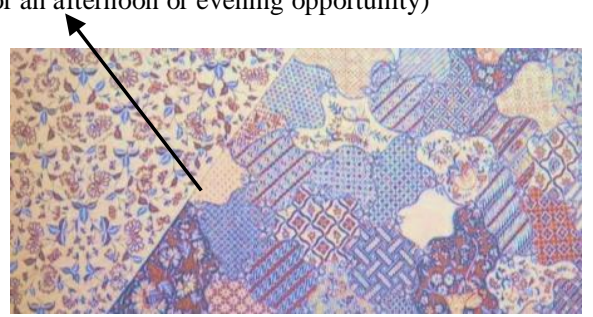

Figure 3. Batik of Esuk-Sore style made by Mrs. Matheron In 1890. (Doc: Repro Dutch Batik 1840-1940) 
Although the mapping batik of Banyumas belonging to coastal batik, but batik works that appear still consistent in the color of the inland dominant classic colors in inland batik such as soga (brown), wedel (blue) and kelengan (black, mix between Brown with blue). Similarly to batik Matheron's Esuk-Sore style, the classic hinterland's color dominance is still very thick, with a blend of classical "Sekar Jagad" motifs on the "right" side and chrysanthemum motifs on the "left" side.

Starting from here then the style of Esuk-Sore spread to several areas adjacent to Banyumas such as Pekalongan, Pemalang, and developed on the north coast of Java Island to Lasem, even Madura, with various innovations and creations of each batik maker.

\section{Essence of batik style Esuk-Sore}

From the data reduced both through interviews or obtained through literature review, there is something very interesting from batik Esuk-Sore style which has been conceived according to the views of previous researchers. So far, when talking about the problems of batik Esuk-Sore, then the naturalization of the concept that has been buried in the subconscious is always associated with difficult times will be the main ingredient of batik maker that is mori or cotton fabric. The concept that always arises is batik as a functional visual expression that is limited by the limitations of the media, in this case the cloth as the main media. So the product appears very limited space motion by one thing. In other words, Esuk-Sore batik product culture becomes a very "socialist" and "materialist" work without looking behind it visually.

There is a fairly basic difference when speaking of Aesthetics in the West and Aesthetics in the East (read: Java). It seems that the conceptual understanding in Eastern aesthetics about all that is said to be "artwork" is always associated with the totality of art workers, batik creators, and artists with a "behavior" or process of getting closer to the Creator, or in other words worshiping. This concept is the basis of batik Esuk-Sore emerged as a local wisdom or local genius full of invisible values.

The works of classical archipelago tradition, such as batik in the process of its creation will always pass the stage of contemplation in every sheet of motif from a long fabric created. A batik creator is a plenary designer who is able to visionary capture the essence of the work to be made, and is destined for what it is made, and what hope or prayer is contained from the visual symbols embodied on a piece of cloth. For example, a long cloth with the motif "sido mukti" or "sido luhur", perhaps when we see the visual form of the fabric outwardly we will only find some decorations that are there like lar (bird wings), dampar (statues), Tree of
Life, and Butterfly or Bird (Kusrianto, 2013, p.133). The four kinds of ornamental is the result of abstraction (contemplation ending in visual expression) whose edges are prayers or expectations when the batik cloth is finished and worn on certain occasions. Perhaps we have not thought about why there are decorations dampar or statues there, why there are decorations of lar or bird wings that just one side there, that is a cultural wisdom of the masterpiece of the nation that has been recognized by the world.

Similarly, batik Esuk-Sore, which we have understood is limited to the trend or style, which in the modern view is always associated with fashion, or fashion in dress. Talking of fashion or fashion issues will always be related to the market or commodity. This is what is currently trapping our mindset in understanding an essence from the adiluhung work of the nation in the form of batik cloth. The concept of the balance of batik Esuk-Sore is felt when looking at the division of the pattern is bounded by a slash in the middle. There are also some Batik Esuk-Sore whose pattern of division is not a slash but a vertical line right in the middle. These two pattern-division techniques are usually associated with techniques or how to wear long cloth from each region. Vertical lines are usually for batik Esuk-Sore Lasem and Madura area, while for Pekalongan, Pemalang, Banyumas, usually using a slash in the middle.

The essence of equilibrium in the world of Eastern philosophy becomes a core teaching of a life. The existence of two different things but one unity becomes a philosophy in understanding and understanding life. There are up, down, dark, light, there is morning or afternoon, night, there are men, there are women, there is life there is death, these two different things are able to position according to their respective roles that culminate in equilibrium. Between men and women as distinct figures both physically and non-physically apparently able to be united in a marriage bond. From a marriage harmonization will emerge a new life that generates the next generation of life that continues to be sustainable.

A difference in the view of Eastern philosophy is not necessarily contested, but is united to bring about a new life, this is true for those who adopt a pattern of marriage or harmonization, which is more aligned with life itself (Sumardjo, 2006, p.30). Different from the pattern of war, where two different things must be disputed. In a real war there will be death, from death a new life will emerge. The principle of domination becomes a concept in this pattern, where between men and women are more dominant where, if men become a win or dominant position, it will appear the concept of boys is more expected than girls. Male lineage becomes more important than women with children. Married couples in the pattern of war must also be separated, so 
there is a woman's house there is a man's house. There is a women's room there is a man's room in one house, and the dividing line must be clear. War and death are spiritual needs, or religious needs. Different mindsets between the gathering society and the cultivators become the initial concept of two different patterns, although they are essentially the same for generating new life. The basis of the minds of the gatherers is to pick, pluck, snatch, kill existing ones. Different from the mindset of the farmers or farmers with the activities of planting, giving, enlivening, growing, marrying and harmonizing existing ones. (Sumardjo, 2006, p.41).

From the side of Esuk-Sore, then popular with the early morning on the north coast of Java which is predominantly Chinese citizens who in this case as makers and who wear this cloth, then the allegation in incorporating the concept of "Yin-Yang" which is manifestation of the balance concept that believed by Chinese citizens is very possible. The results of interviews with Istyanti who is the second generation of legendary batik successor Oey Soe Tjoen had told about this, although it is still very implied. A very high appreciation on batik Esuk-Sore by making "sacred" its use. Even the impression parallel with the classic batik motifs inland "sido mukti" which in the "sacred" Javanese society for ritual "meeting" at the wedding ceremony Java. There is a similarity in the usage function between "sido mukti" and "Esuk-Sore", perhaps it is interesting to examine further the findings of a phenomenological approach that still requires much data for a degree of validity in attracting the reduction of existing data.

\section{The existence of Batik Esuk-Sore style.}

Batik Esuk-Sore style currently more emerging from the side of the concept of solid-match, meaning batik Esuk-Sore is no longer made as a long cloth (jarit), but more used for clothing. Utilization of long cloth at this time is not many who wear, even said no one to wear again. In terms of value, there is degradation of value that appears there, from the sacred to the profane, but in terms of economic value there is an increase. Batik cloth originally sacred and used only once a year or at certain moments into batik cloth that can at any time be used when morphed into clothing with the concept of solid-matching Esuk-Sore.

A sustainability of the emerging or the lost styles is understood as a fashion trend that follows the tastes of the consumer or the ever-dynamic market and moves with the rapidly changing age. There is a positive side to this shift in concept which in fact is more in favor of the desire of the market that always wants to change and develop following the "western" economic principles. Currently when we speak at the level of defense, there are two patterns of thought that must be followed that is the pattern of commodification or the pattern of values of traditions that become the root of where the direction of this defense will be brought.

When it will be brought to the realm of commodification, need thoroughness in innovating and creative from conception of solid-matrix of batik EsukSore so that can be accepted by society at large in terms of market of course. However, when it will be brought in the realm of the value of tradition, how the efforts of supporters or buffer society from batik Esuk-Sore is able to survive to live the values of the greatness of batik, especially in implementing it in everyday life.

\section{Conclusion.}

Based on the discussion about batik "Esuk-Sore" above, one can be drawn a conclusion that in the application in society, the four social components such as artists, buffer society, structural institutions, and mediators between each other interrelated and synergize. The existence of these components is interconnected with one another, creating a social order or construction that supports the existence of batik "Esuk-Sore". The existence of batik "Esuk-Sore" which emerged as a trend in the coastal island of Java is very adaptive to the situation of the times that continue to run. Local wisdom of the nation emerges as an innovation force in the effort of cultural defense naturally, depending on the perspective of where sustainability and sustainability of batik-style Esuk-Sore it will be preserved and preserved naturally.

\section{Bibliography}

Becker, H. S. (1982). Art World. Berkeley: University of California.

Djoemena, N. S. (1990). Ungkapan Sehelai Batik, Its Mistery and Meaning. Jakarta: Djambatan.

Duvignaut, J. (1972). The Sociology of Art, terjemahan Timothy Wilson. London: Granada Publishing Limited.

Helen Ishwara, L. S. (2011). Batik Pesisir Pusaka Indonesia Koleksi Hartono Sumarsono. Jakarta: Kepustakaan Populer Gramedia.

Kayam, U. (1981). Seni Tradisi dan Masyarakat. Yogyakarta: PT. Sinar Harapan. 
Kuntowijoyo. (1987). Budaya dan Masyarakat. Yogyakarta: PT Tirta Wacana.

Kusrianto, A. (2013). Batik-Filosofi, Motif dan Kegunaan. Yogyakarta: CV Andi Ofset.

Sumardjo, J. (2006). Estetika Paradoks. Bandung: Sunan Ambu Press STSI Bandung.

Veldhuisen, H. C. (1993). Batik Belanda 1840-1940. Jakarta: Gaya Favorit Press.

Williams, R. (1983). Culture. Glasgow: William Collins \& Co.Ltd.

\section{Interviewer:}

Name: Dudung Alisyahbana

Age: 58 years

Occupation: Batik businessman

Address: Pekalongan

Name: Istyanti Setyono

Age: 64 years old

Occupation: Batik Businessman

Address: Kedung Wuni Pekalongan

Name: Danarti

Age: 43 years old

Occupation: Trader of antic (collector of batik)

Address: Yogyakarta

Name: Rostami

Age: 50 years

Occupation: Housewife (Activist women activity)

Address: Solo

Name: Afif Gratitude

Age: 50 years

Occupation: Batik businessman, batik collector

Address: Pandega Marta, Yogyakarta 